\title{
TROŠKOVI PARNIČNOG POSTUPKA U SLUČAJU DJELOMIČNOG USPJEHA U SPORU
}

Izv. prof. dr. sc. Dinka Šago*

\author{
UDK 347.921.6 \\ https://doi.org/10.30925/zpfsr.42.2.10 \\ Ur.: 16. veljače 2021 . \\ Pr.: 10. ožujka 2021. \\ Pregledni rad
}

\begin{abstract}
Sažetak
U članku se analiziraju pojedina rješenja Novele Zakona o parničnom postupku iz 2019. o naknadi troškova prema načelu odgovornosti za uspjeh te odgovornosti za krivnju, odnosno slučaj. Analiziraju se novine u odnosu na djelomični uspjeh stranaka u parnici, uspjeh u dokazivanju osnove tužbenoga zahtjeva, promjena vrijednosti predmeta spora tijekom parnice, sudjelovanje umješača, povlačenje tužbe $i$ odricanje od tužbenoga zahtjeva te troškovi u povodu sudjelovanja privremenog zastupnika u parnici.
\end{abstract}

Ključne riječi: troškovi; parnični postupak; djelomični uspjeh stranaka u sporu.

\section{UVOD}

Parnični troškovi su izdatci nastali tijekom ili u povodu postupka. Oni obuhvaćaju i nagradu za rad odvjetnika i drugih osoba kojima zakon priznaje pravo na nagradu (čl. 151. Zakona o parničnom postupku, dalje: ZPP). ${ }^{1}$ Riječ je o troškovima koji su nastali tijekom postupka, ali i onima koji su neposredno uzrokovani sudjelovanjem stranke ili drugih procesnih subjekata u postupku i odnose se na poduzimanje različitih procesnih radnji. ${ }^{2}$

Odredbe ZPP-a u dijelu koji uređuje parnične troškove naizgled su jednostavne, ali u praksi stvaraju brojne dvojbe i otvaraju mnoga pitanja. Naknada troškova uređena je odredbama čl. 151. do 172. ZPP-a, s tim da je materija parničnih troškova propisana u čl. od 151. do 167., dok je odredbom čl. 168. uređeno pitanje snošenja troškova postupka osiguranja dokaza, a čl. 172. oslobođenje od plaćanja troškova postupka.

Kad govorimo o troškovima u povodu postupka, riječ je o troškovima koje je imala stranka koja radi zaštite svojih subjektivnih prava namjerava pokrenuti parnični

* Dr. sc. Dinka Šago, izvanredna profesorica, Pravni fakultet Sveučilišta u Splitu; dsago@pravst. hr. ORCID: https://orcid.org/0000-0002-2957-2761.

1 Zakon o parničnom postupku, Narodne novine, br. 53/91., 91/92., 112/99., 88/01., 117/03., 88/05., 2/07. - Odluka US RH, 84/08., 96/08. - Odluka US RH, 123/08. - ispravak, 57/11., 148/11. - 25/13., 28/13., 89/14., 70/19. (dalje: ZPP).

2 Vidi Vicko Prančić, „O naknadi pretprocesnih troškova u parničnom postupku“, Zbornik Pravnog fakulteta u Splitu 47, br. 4 (2010): 861-886. 
postupak, ${ }^{3}$ ali prije te radnje mora podnijeti zahtjev za mirno rješenje spora ${ }^{4}$ ili taj zahtjev može podnijeti radi ostvarivanja nekih prava uz glavni zahtjev bilo da je to povezano s meritumom spora ${ }^{5}$ ili se odnosi na sporedne tražbine, kao što je to zatezna kamata. ${ }^{6}$

Za razliku od troškova koji se pojavljuju u povodu postupka, parnični troškovi nastali tijekom postupka odnose se na one troškove koji su potrebni radi dokazivanja određenih činjenica (troškovi izvođenja dokaza, troškovi dolaska svjedoka) i troškovi zastupanja. $^{7}$

\section{NAČELA U PRIMJENI PRI ODLUČIVANJU O TROŠKOVIMA}

Domaća sudska praksa i pravna doktrina temelje se na stajalištu da su za konačno snošenje troškova postupka odlučna dva kriterija, odnosno načela i to načelo causae, odnosno načelo odgovornosti za uspjeh u parnici i načelo culpae, odnosno odgovornosti zbog krivnje ili slučaja. ${ }^{8}$ Osnovno načelo naknade troškova postupka kriterij je uspjeha u parnici koji je nametnut kao temeljno načelo za prosudbu o tome koja će od stranaka biti dužna protivnoj stranci i njezinu umješaču naknaditi troškove postupka. Prema odredbi čl. 154. st. 1. ZPP-a, stranka koja je uspjela u parnici ima pravo na naknadu troškova na teret protivne stranke koja, uz te troškove, mora snositi i vlastite parnične troškove.

Taj je kriterij objektivno određen jer pravo na naknadu troškova ovisi o ishodu parnice kao objektivnoj okolnosti. Pritom nije odlučno je li stranka koja je izgubila spor skrivila njezino vođenje, odnosno nastanak troškova. To je ujedno objektivizirani

3 Vidi Sanja Mišević, „Pretprocesni parnični troškovi“, Aktualnosti hrvatskog zakonodavstva i pravne prakse: građansko, trgovačko, radno i procesno pravo u praksi: godišnjak 22 (2015): 683-690.

4 Osoba koja namjerava podnijeti tužbu protiv Republike Hrvatske dužna je prije podnošenja tužbe obratiti se sa zahtjevom za mirno rješenje spora državnom odvjetništvu koje je stvarno i mjesno nadležno za zastupanje na sudu pred kojim namjerava podnijeti tužbu protiv Republike Hrvatske. Isto vrijedi i kada Republika Hrvatska namjerava tužiti neku osobu s prebivalištem ili sjedištem u Republici Hrvatskoj. Riječ je o procesnoj pretpostavci za podnošenje tužbe, pa pri odlučivanju o troškovima postupka o toj važnoj činjenici treba voditi računa.

5 Ako je riječ o pokretanju postupka koji prethodi parničnom postupku, a vezan je za ostvarenje prava koja su povezana s meritumom spora, tada je riječ o troškovima postupka za osiguravanje dokaza. Te troškove podmiruje stranka koja je podnijela prijedlog za osiguranje dokaza. Ona je obvezna nadoknaditi i troškove protivnoj stranci, odnosno postavljenom privremenom zastupniku. No, te troškove stranka može naknadno ostvarivati kao dio parničnih troškova, prema uspjehu u parnici.

6 Kao troškovi nastali prije pokretanja parnice pojavljuju se troškovi zahtjeva za mirno rješenje spora u odštetnim parnicama. Međutim, ti troškovi nisu procesni troškovi i ne moraju niti nastati kada stranka ne podnese taj odštetni zahtjev, no vežu se uz njezina prava na zateznu kamatu. Naime, kada stranka podnese tužbu radi naknade neimovinske štete tada se njezin zahtjev za zateznu kamatu veže uz podnošenje pisanoga zahtjeva ili tužbe.

7 Više Siniša Triva i Mihajlo Dika, Građansko parnično procesno pravo, 7. izmijenjeno i dopunjeno izd., Narodne novine, Zagreb, 2004., 463-464.

8 Vidi Goranka B. Ručević i Senija Ledić, Troškovi parničnog postupka, Priručnik za polaznike/ ice, Zagreb, Pravosudna akademija, 2018., 16. 
izraz načela davanja povoda za parnicu i time prouzrokovanja troškova postupka. ${ }^{9}$ Vrijednost je predmeta spora, pak, važna za donošenje odluke o parničnim troškovima.

Sukladno načelu causae, uređenim čl. 154. ZPP-a, obveza snošenja parničnih troškova temelji se na uspjehu stranaka u parnici. Za određivanje uspjeha, odnosno neuspjeha stranke u parnici, u kojoj je predmet spora novčani zahtjev, osim uspjeha vezano za osnovu zahtjeva, valja imati na umu i uspjeh glede visine postavljenog zahtjeva. Visina postavljenoga tužbenog zahtjeva (a time i vrijednost predmeta spora) mjerodavna je i za određivanje visine parničnih troškova. Sukladno čl. 155. st. 2. ZPP-a, ako je propisana tarifa za nagrade odvjetnika ili za druge troškove, ti će se troškovi odmjeriti prema toj tarifi. U Tarifi o nagradama i naknadi troškova za rad odvjetnika, ${ }^{10}$ kao i u Zakonu o sudskim pristojbama, ${ }^{11}$ vrijednost predmeta spora temeljni je kriterij za određivanje visine parničnih troškova. Dakle, visina postavljenoga tužbenog zahtjeva u parničnom postupku povezana je s vrijednošću predmeta spora i troškovima parničnog postupka. ${ }^{12}$

Pravo na sudsku zaštitu povezano je s ostvarenjem glavnog zahtjeva, ali i uz naknadu onih troškova koji prate ostvarenje toga zahtjeva u postupku. Zato je pri primjeni načela uspjeha nužno voditi računa o uspjehu u parnici, jer se uz taj uspjeh redovito veže i pravo na naknadu troškova postupka. Ona strana spora koja u cijelosti uspije u sporu, imat će pravo na naknadu troškova postupka u cijelosti. Pritom je nužno voditi računa o tome da su ti troškovi bili potrebni radi vođenja parnice, jer ta strana ima pravo samo na njihovu na naknadu. Ostvarenje ovog načela ostvarit će se kad se primijeni stajalište da je obvezan snositi svoje troškove i naknaditi troškove svome protivniku onaj koji je svojim držanjem prije i izvan parnice doveo do potrebe da se parnica vodi, dakle onaj koji je prouzročio vođenje parnice, koji je dao povoda povredi subjektivnih prava druge strane i zbog toga je izgubio parnicu.

U primjeni načela krivnje treba voditi računa o onim troškovima koje je sama stranka prouzročila svojom krivnjom ili slučajem koji joj se dogodio, pa tada te troškove nije obvezan naknaditi protivnik, bez obzira na uspjeh u postupku. Po načelu culpae stranka je dužna, neovisno o ishodu parnice, dakle i kad uspije u parnici, pa i prije nego što bude donesena odluka o glavnoj stvari, naknaditi protivniku troškove koje mu je tijekom i u povodu parnice prouzročila svojom krivnjom ili slučajem koji joj se dogodio, a tada će snositi i svoje troškove koji su nastali zbog toga.

Kada je riječ o djelomičnom uspjehu u postupku, sud tada može s obzirom na postignuti uspjeh, odrediti da svaka stranka snosi svoje troškove ili da jedna stranka nadoknadi drugoj i umješaču razmjeran dio troškova. Pri odlučivanju o djelomičnom uspjehu u postupku valja voditi računa o kriterijima tog uspjeha i razlikovati

9 Tako i Mihajlo Dika, „Konačno snošenje troškova parničnog postupka, Pokušaj sustavne prezentacije i redefiniranje instituta“. Pravo u gospodarstvu 44, br. 4 (2005): 54-90.

10 Tarifa o nagradama i naknadi troškova za rad odvjetnika, Narodne novine, br. 142/12., 103/14., 118/14. i 107/15.

11 Zakon o sudskim pristojbama, Narodne novine, br. 118/18.

12 Vladimir Vučković, „Promjena visine tužbenog zahtjeva i naknada troškova parničnog postupka: kritika novog zakonodavnog rješenja“"Informator 67, br 6588 (2019): 1-4, pristup 19. prosinca 2020., https://informator.hr/strucni-clanci/promjena-visine-tuzbenog-zahtjeva-inaknada-troskova-parnicnog-postupka-kritika-novog-zakonodavnog-rjesenja. 
kvalitativni i kvantitativni uspjeh. ${ }^{13,14}$

\section{KVALITATIVNI I KVANTITATIVNI USPJEH}

VSRH zauzeo je pravno shvaćanje prema kojem je potrebno pri određivanju troškova postupka izraze ,djelomični uspjeh“ i „razmjerni dio troškova“, koji su obuhvaćeni u odredbi čl. 154. st. 2. ZPP-a, ocjenjivati ne samo kvantitativno već i kvalitativno s obzirom na osnovu i na visinu prihvaćenog, odnosno odbijenog dijela tužbenog zahtjeva. ${ }^{15}$ Zbog toga ako je tuženik osporavao osnovu tužbenog zahtjeva u potpunosti ili samo osnovu pojedinih samostalnih dijelova zahtjeva, zbog čega su izvršena vještačenja i izvedeni drugi dokazi za koje je tužitelj prethodno snosio troškove, tužitelju se priznaju takvi troškovi u cijelosti, bez obzira na visinu dosuđenog iznosa. ${ }^{16}$ Pri odlučivanju o ostalim troškovima parničnog postupka treba, u pravilu nužno je uzeti u obzir i tužiteljev i tuženikov uspjeh u parnici. Ako tuženik osporava samo visinu zahtijevane naknade pojedinog oblika neimovinske štete, sud će cijeniti treba li tužitelju u cijelosti ili samo djelomično priznati troškove oko utvrđivanja visine neimovinske štete koju je tužitelj prethodno snosio, a u odnosu na visinu dosuđene mu naknade. ${ }^{17} \mathrm{U}$ praksi se često događa da sudovi odlučuju samo o troškovima tužitelja i obvezuju tuženika na plaćanje troškova tužitelju srazmjerno njegovu uspjehu u parnici, ne osvrćući se na troškove tuženika i njegov uspjeh u parnici, što je pogrešno. Uspjeh ili neuspjeh tužitelja u parnici razmjeran je uspjehu ili neuspjehu tuženika u parnici i oni moraju biti ravnopravni u parnici. ${ }^{18}$

Takvo pravno shvaćanje VSRH jasno ukazuje na to da kod odlučivanja o uspjehu stranke u postupku treba odlučivati o uspjehu tužitelja u sporu, ali i o uspjehu tuženika u istom postupku. Prema tome, nema mjesta odluci o troškovima na način da se u povodu pokrenute parnice utvrđuje samo uspjeh tužitelja u postupku.

Kvalitativno ocjenjivanje uspjeha u sporu najčešće je povezano s troškovima

13 Tužitelj u reviziji pobija i odluku nižestupanjskih sudova o naknadi parničnih troškova polazeći pri tome od tumačenja članka 154. stavak 2. ZPP-a koje je po shvaćanju ovog revizijskog suda pogrešno. Ta zakonska odredba glasi: „,Ako stranka djelomično uspije u parnici, sud može, s obzirom na postignuti uspjeh, odrediti da svaka stranka podmiruje svoje troškove ili da jedna stranka nadoknadi drugoj i umješaču razmjeran dio troškova “. Iz tog propisa nikako ne slijedi tužiteljev zaključak da jedino tužitelj može djelomično uspjeti u parnici. Protivno njegovim revizijskim navodima, upravo djelomični neuspjeh tužitelja (tj. odbijanje dijela tužbenog zahtjeva) znači ujedno i tuženikov uspjeh, pa stoga odluka nižestupanjskih sudova o parničnim troškovima nije pogrešna. U tom smislu presuđeno: Vrhovni sud Republike Hrvatske (dalje: VSRH), Rev - 200/2001-2. Vidi i Damir Jelinić, „(Po)nešto o nedopuštenosti revizije protiv pravomoćnog rješenja o naknadi troškova parničnog postupka“, Hrvatska pravna revija 7/8 (2016): 72-78.

14 Adis Poljić, Troškovi parničnog postupka i vrijednost predmeta spora (Sarajevo: Privredna štampa, 2019.), 98.

15 Presuda i rješenje VSRH, Rev-388/00 od 26. kolovoza 2003.

16 Zaključak VSRH sa sjednice održane 6. lipnja 1980.: PSH Pž-3325/90 od 14. siječnja 1992.

17 Vidi Branko Hrvatin, „Naknada troškova parničnog postupka“, Hrvatska gospodarska revija br. 11 (1998): 37.

18 Čizmić, Jozo, Komentar Zakona o parničnom postupku, 2. izmijenjeno i dopunjeno izd. (Sarajevo: Privredna štampa 2016), 1118. 
vještačenja ili očevida, pa se oni u pravilu priznaju onoj stranci u postupku koja je predujmila te troškove i pri tome se ne umanjuju prema postignutom uspjehu.

Može se postaviti pitanje treba li na taj način ocjenjivati uspjeh stranaka i kod djelomičnoga povlačenja tužbe kad se prema vrijednosti konačno postavljenog zahtjeva i vrijednosti prvotno postavljenog većeg zahtjeva plaća isti trošak zastupanja prema Tarifi o nagradama i naknadi troškova za rad odvjetnika (dalje: Odvjetnička tarifa). ${ }^{19}$ Takvi se problemi redovito pojavljuju kod parnica radi naknade štete kad tužitelj u tužbi postavi određeni zahtjev za isplatu, a nakon provedenog vještačenja smanji zahtjev, ali tako da oba zahtjeva po vrijednosti ulaze u isti trošak zastupanja prema Odvjetničkoj tarifi (Tbr. 7. toč. 1.). Kod odgovora na ovo pitanje treba imati na umu pravna shvaćanja VSRH, koji je u nizu svojih odluka izrazio pravno shvaćanje o tom problemu pri odlučivanju o troškovima postupka kod djelomičnog povlačenja tužbe. ${ }^{20}$

Nužno je ponajprije voditi računa o tome da se trošak parničnog postupka određuje sukladno vrijednosti predmeta spora koja je vrijedila u trenutku poduzimanja pojedine parnične radnje, a ne prema vrijednosti predmeta spora koja je eventualno vrijedila pri zaključenju glavne rasprave. Uz to, troškovi parničnog postupka odmjeravaju se razmjerno uspjehu u odnosu na vrijednost predmeta spora koja je vrijedila u trenutku zaključenja glavne rasprave. ${ }^{21}$

\section{DJELOMIČNI USPJEH U SPORU DO NOVELE ZPP-A 2019.}

Prije donošenja Zakona o izmjenama i dopunama Zakona o parničnom postupku 2019. (Novela 2019.), ${ }^{22}$ u sudskoj se praksi primjenjivao matematički obračun troškova u kojem se gotovo u cijelosti izgubila važnost dokazivanja utemeljenosti zahtjeva (kvalitativno), vodeći se samo uspjehom u pogledu visine zahtjeva (kvantitativno). ${ }^{23}$

19 Tarifa o nagradama i naknadi troškova za rad odvjetnika, Narodne novine, br. 142/12., 103/14., 118/14., 107/15.

20 Opširnije Mihajlo Dika, „Naknada troškova u slučaju povlačenja tužbe i odricanja od tužbenog zahtjeva prema noveliranom Zakonu o parničnom postupku“, Zbornik Pravnog fakulteta Sveučilišta u Rijeci 41, br. 1 (2020): 1-40.

21 Vidi presudu i rješenje VSRH, Revr-1345/09 od 12. siječnja 2010. i Rev 583/09 od 17. rujna 2013.

22 Zakon o izmjenama i dopunama Zakona o parničnom postupku, Narodne novine, br. 70/19.

23 S obzirom da je ovaj sud djelomično preinačio nižestupanjske presude odlučio je o troškovima cijelog postupka (čl. 166. st. 2. i čl. 154. st. 2. ZPP). Kako je tužitelj istaknuo tužbeni zahtjev u iznosu od 181.260,00 kn sa kamatama, a konačno mu je tužbeni zahtjev prihvaćen do iznosa od 121.500,00 kn sa kamatama, u sporu je uspio u $67 \%$ dijela, a tuženik u $33 \%$ dijela. Tužitelj je imao izdataka za sastav tužbe $i$ drugih podnesaka te za zastupanje odvjetnika ukupno u iznosu od 35.007,90 kn, a s obzirom na uspjeh u sporu pripada mu pravo na naknadu u iznosu od 23.455,29 kn i naknada troška vještačenja u iznosu od 11.272,60 kn, što ukupno iznosi $34.727,89 \mathrm{kn}$. Tuženik je imao izdataka za sastav podnesaka i zastupanje u iznosu od 11.500,00 $\mathrm{kn}$, sastav žalbe 3.125,00 kn, sastav revizije 7.500,00 kn, što ukupno iznosi 22.125,00 kn, a s obzirom na uspjeh u sporu pripada mu pravo na naknadu u iznosu od 7.301,25 kn. Nakon izvršenog prijeboja tražbina naknade parničnih troškova ostala je razlika u iznosu od 27.426,64 kn u korist tužitelja, te je tuženik taj iznos platiti tužitelju na ime naknade parničnih troškova..., VSRH, Rev 832/05-2. 
Prema čl. 154. st. 2. ZPP-a sud bi, ovisno o uspjehu u parnici, a u slučaju djelomičnog uspjeha u sporu, ${ }^{24}$ mogao odrediti da svaka stranka ${ }^{25}$ snosi svoje troškove ili da jedna stranka nadoknadi drugoj i umješaču razmjeran dio troškova.

Postojale su dvije mogućnosti, odnosno opcije naknade, prva, rezervirana za jednaki parnični (ne)uspjeh u sporu, u kojoj je parnični sud ponaosob obvezivao stranke na podmirenje njihovih parničnih troškova, i druga, rezervirana za situacije većega djelomičnog uspjeha jedne stranke u kojoj bi parnični sud prvo:

- utvrdio djelomični parnični uspjeh stranaka, ${ }^{26}$

- obračunao njihove parnične troškove za koje je smatrao da su bili nužni za vođenje parnice,

- prebio dobivene novčane iznose troškova, zatim ih razmjerno umanjio sukladno (ne)uspjehu u sporu ${ }^{27} \mathrm{i}$

- $\quad$ stranku koja je u manjem dijelu djelomično uspjela u sporu obvezao na naknadu dobivenoga razmjernog iznosa troškova protustranke koja je postigla, odnosno polučila veći djelomični parnični uspjeh. ${ }^{28}$

Iako prije nije bila normirana obveza da se pri utvrđivanju troška u obzir uzmu

$24 U$ tom smislu presuđeno: $S$ obzirom da je ovaj sud djelomično preinačio pobijanu presudu odlučio je o troškovima cijelog postupka (čl. 166/2. u vezi čl. 154/2. ZPP). S obzirom na istaknuti tužbeni zahtjev i dosuđeni iznos naknade štete presudom ovog suda proizlazi da je tužiteljica u parnici uspjela u $16 \%$ dijela, a tuženik u $84 \%$ dijela. Tužiteljica je imala za sastav tužbe i ostalih podnesaka putem odvjetnika u iznosu od 141.276,00 kn, a s obzirom na uspjeh u parnici pripada joj pravo na naknadu u iznosu od 22.604,16 kn, te u cijelosti naknada troškova vještačenja - 2.500,00 kn, što ukupno iznosi 25.104,00 kn. Tuženik je imao izdataka za sastav podnesaka i zastupanje odvjetnikom u iznosu od 89.410,00 kn, trošak vještačenja u iznosu od 12.640,00 kn, troškova žalbe podnesene protiv prvostupanjske presude u iznosu od $6.875,00 \mathrm{kn}$, troškova revizije u iznosu od $6.037,50 \mathrm{kn}$, što ukupno iznosi $114.962,50 \mathrm{kn}$, a s obzirom na uspjeh u parnici pripada mu pravo na naknadu u iznosu od 96.568,50 kn. Nakon izvršenog prijeboja tražbina naknade parničnih troškova razlika je u korist tuženika u iznosu od 71.464,50 kn, te je tužiteljica dužna taj iznos platiti tuženiku na ime naknade parničnih troškova., VSRH, Rev 616/2006-2.

25 Svaka stranka, a ne samo tužitelj, može djelomično uspjeti u parnici..., VSRH, Rev 200/2001.

26 Pri odlučivanju o troškovima parničnog postupka vodi se računa kako o tužiteljevu tako i o tuženikovom uspjehu u parnici..., VSRH, Rev 2141/1995.

27 Kada je tužbenom zahtjevu samo djelomično udovoljeno treba kod odlučivanja o parničnim troškovima uzeti u obzir i tužiteljev i tuženikov uspjeh u parnici., VSRH, Rev 3146/1990.

28 Odluka o parničnom trošku je preinačena pozivom na čl. 166/2., čl. 154/2. i čl. 155. ZPP-a. Tužiteljica je imala parnični trošak za sastav tužbe u visini 330 bodova (Tbr. 7. toč. I. Tarife o nagradama i naknadi troškova za rad odvjetnika) za zastupanje na ročištima 21.10.2002., 18. svibnja 2003. i 21. studenog 2003. godine, ukupno 990 bodova (Tbr. 9. Tarife), odnosno ukupno 1320 bodova, što sa PDV-om iznosi 16.104,00 kn. Tužiteljica je uspjela u parnici u omjeru koji iznosi $40 \%$, te joj kao opravdan parnični trošak pripada iznos od $6.441,60 \mathrm{kn}$. Tuženik je imao trošak sudskih pristojbi na tužbi i presudu u iznosu od 6.700,00 kn, s time da je uspio u protivljenju tužbenom zahtjevu u omjeru od $60 \%$ (u kojem je omjeru tuženik uspio u parnici), pa mu kao opravdan parnični trošak pripada iznos od 4.020,00 kn. Nakon izvršsenog prijeboja parničnih troškova tuženom je naloženo da plati tužiteljici parnični trošak u ukupnom iznosu od 2.421,60 kn., VSRH, Rev 885/2006-2. Vidi Damir Jelušić, „Novo normativno rješenje instituta naknade parničnih troškova u situaciji parcijalnog uspjeha u sporu“, Pravo i porezi, 11 (2019): 82-85, pristup 17. prosinca 2020., https://www.iusinfo.hr/strucni-clanci/ CLN20V01D2019B1291_,1. 
i kvantitativni i kvalitativni način obračuna, stajalište sudske prakse o važnosti usmjeravanja prema objedinjenju izražena je u Zaključku sjednice 3/80 Građanskog odjela VSRH od 6. lipnja 1980.

Navedeni je zaključak postao temelj za različite buduće revizijske odluke kao i za ujednačavanje prakse sudova. ${ }^{29,}{ }^{30}$ Zaključkom je utvrđeno da pri odlučivanju o troškovima parničnog postupka vodi se računa kako o tužiteljevu tako i o tuženikovom uspjehu u parnici. ${ }^{31}$

Nadalje, pozivajući se na navedenu presudu, uređene su i drukčije situacija. Primjerice, za razliku od navedenoga ,pravila“, gdje se trošak razmjerno nadoknađuje objema stranama, postoje situacije u kojima se trošak priznaje samo tužitelju. ${ }^{32}$ Prema Rev - 1140/2006 od 10. listopada 2007. kada je tuženik neutemeljeno osporavao osnovu tužbenog zahtjeva, zbog čega je tužitelj predujmio određene parnične troškove, tužitelju bi trebalo te troškove priznati u cijelosti, bez obzira na to što je njegov tužbeni zahtjev bio djelomično prihvaćen. Kada je tuženik osporio samo visinu zahtijevane naknade pojedinog oblika neimovinske štete, sud će ocijeniti treba li tužitelj u cijelosti ili samo djelomično priznati troškove utvrđene visine neimovinske štete koje je tužitelj

29 Npr. Pravno shvaćanje se sastoji u tome da kod odlučivanja o troškovima parničnog postupka treba pravilno uzimati kako tužiteljev, tako i tuženikov uspjeh u parnici, a kod parcijalnog uspjeha stranaka u sporu potrebno je prilikom određivanja troškova postupka ocjenjivati ne samo kvantitativno, već i kvalitativno uspjeh stranaka i to kako s obzirom na osnovu, tako $i$ s obzirom na visinu prihvaćenog odnosno odbijenog dijela tužbenog zahtjeva..., VSRH, Rev 817/13-2.

30 Tuženici podnose reviziju s pitanjem primjene odredbe čl. 154. st. 2. Zakona o parničnom postupku te presuđenja da svaka od stranaka snosi svoje troškove iako je jedna od stranaka (tuženici) u pretežitom dijelu uspjela sa parnicom. Razmjeran uspjeh ili pretežiti uspjeh $u$ sporu ne mora biti samo matematički rezultat uspjeha gledano s obzirom na razliku između dosuđenog novčanog iznosa u odnosu na traženi iznos u novcu. Ovo stoga što onda odredba čl. 154. st. 2. ZPP-a ne bi mogla biti primjenjiva u sporovima koji za predmet raspravljanja imaju nenovčani zahtjev. Razmjeran uspjeh se sagledava kvantitativno i kvalitativno s obzirom na sve okolnosti vezane za konkretni spor. Zato po shvaćanju ovog suda, rješenje navedenog pitanja ovisi o okolnostima svakog konkretnog slučaja, a kako okolnosti konkretnog slučaja u pojedinim sporovima mogu biti različite, onda i odgovor na postavljeno pitanje ne mora uvijek biti jednoznačan..., VSRH, Rev-x 502/12-2.

31 VSRH, Rev 2141/1995.

32 ...Isto tako, u svezi razmjernog uspjeha stranaka u postupku, ovaj sud je još na sjednici Građanskog odjela od 6. lipnja 1980. zauzeo pravno shvaćanje da je pri parcijalnom uspjehu stranaka u postupku (čl. 154. st. 2. ZPP-a) potrebno prilikom određivanja troškova postupka izraze , djelomičan uspjeh" $i$, ,razmjerni dio troškova" ocjenjivati ne samo kvantitativno već $i$ kvalitativno, kako s obzirom na osnovu, tako is obzirom na visinu prihvaćenog, odnosno odbijenog dijela tužbenog zahtjeva, pa stoga u slučaju: - kad je tuženik osporavao osnovu tužbenog zahtjeva u potpunosti ili samo osnovu pojedinih samostalnih dijelova zahtjeva (pojedini oblik štete $i$ slično), zbog čega su napravljena vještačenja i izvedeni drugi dokazi za koje je tužitelj prethodno snosio troškove, tužitelju će se priznati takvi troškovi u cijelosti, bez obzira na visinu dosuđenog iznosa, a kad je tuženik osporio samo visinu zahtijevane naknade pojedinog oblika neimovinske štete, sud će ocijeniti treba li tužitelju u cijelosti ili samo djelomično priznati troškove utvrđivanja visine neimovinske štete koje je tužitelj prethodno snosio, a u odnosu na visinu dosuđene mu naknade (koje pravno shvaćanje je izneseno $i$ u odluci ovog suda na koju se tužitelj poziva u reviziji: Rev - 1083/09 od 15. listopada 2009.), VSRH, Revr 119/12-2. 
prethodno snosio, a u odnosu na visinu dosuđene naknade. ${ }^{33}$

\section{UREĐENJE U NOVELI 2019.}

Potreba za izmjenama i dopunama Zakona o parničnom postupku nastavak je rada na otklanjanju problema u primjeni zakona i unaprjeđenju funkcionalizacije pravosudnog sustava, ubrzanju i skraćivanju trajanja sudskih postupka, a time i smanjenju troškova parničnog postupka. ${ }^{34}$ Novelom 2019. uvelike su izmijenjena pravila koja se primjenjuju u slučaju djelomičnog uspjeha stranaka u parnici u pokušaju, prevladavanja problema koji su se pojavili u sudskoj praksi. ${ }^{35}$ Uspjeh u parnici ocjenjuje se prema konačno postavljenom tužbenom zahtjevu, pritom vodeći računa i o uspjehu dokazivanja u pogledu osnove zahtjeva. Uvedena je i odredba kojom sud može odrediti da jedna stranka naknadi drugoj pojedine troškove, cijeneći postupanje jedne ili druge stranke u korist ili protiv pokušaja mirnog rješenja spora. $\mathrm{Na}$ te se odredbe odnosi jedna od iznimaka stupanja na snagu, nova pravila o troškovima koja će se primjenjivati i u svim sporovima koji su započeti prije 1. rujna 2019. dakle prije stupanja na snagu Novele 2019., a u kojima nije donesena prvostupanjska odluka.

Pritom treba istaknuti razlikovanje između naknade troškova u slučaju u kojemu su stranke djelomično, ali nejednako uspjele u parnici, od onoga u kojemu su stranke uspjele u parnici u približno jednakim dijelovima. ${ }^{36} \mathrm{~S}$ obzirom na to da takav način obračuna troškova nije bio normiran sve do Novele 2019., nije bilo obveza primjene, već se primjenjivao kroz naprijed navedenu presudu VSRH. Sukladno novom normativnom rješenju, ako su stranke u sporu uspjele djelomično, nadoknađuju troškove razmjerno i ovisno o svom uspjehu. ${ }^{37}$

Novelom ZPP 2019. propisuje se da ako stranka djelomično uspije u parnici, sud može s obzirom na postignuti uspjeh, odrediti da svaka stranka snosi svoje troškove ili

33 Zinka Bulka, „Troškovi parničnog postupka i matematika- (ne)pravda za tužitelja“, Pravo i porezi 21, br. 7/8 (2012): 63 .

34 Prijedlog Zakona o izmjenama i dopunama Zakona o parničnom postupku, 29. ožujka 2019., Vlada Republike Hrvatske, 1, https://www.sabor.hr/sites/default/files/uploads/ sabor/2019-03-28/155302/PZ_620.pdf.

35 Dragan Katić, Željko Pajalić i Aleksandra Maganić, Izmjene Zakona o parničnom postupku, Priručnik za polaznike/polaznice, Izrada obrazovnog materijala (Zagreb, Pravosudna akademija, 2019.), 28-30.

36 Slađana Aras Kramar, „Troškovi parničnog postupka - osvrt na važna pitanja“, Pravo i porezi br. 10 (2020): 48-56.

37 Tuženik je u reviziji naznačio pravno pitanje - da li se kod djelomičnog uspjeha stranaka u parnici kod donošenja odluke o parničnim troškovima uzimaju u obzir parnični troškovi obje parnične stranke. Drugostupanjski sud je u odluci o parničnim troškovima obvezao tuženika na naknadu troškova razmjerno uspjehu tužitelja u parnici, ne uzimajući u obzir i parnične troškove tuženika. Takvo pravno shvaćanje drugostupanjskog suda nije pravilno, te je protivno pravnom shvaćanju ovog suda: ...kad stranke djelomično uspiju u parnici, sud će najprije utvrditi iznos naknade troškova na koji svaka stranka ima s obzirom na svoj uspjeh u sporu. Nakon toga će navedene iznose prebiti i razliku dosuditi onoj stranci koja ima pravo na naknadu većeg iznosa parničnih troškova..., VSRH, Rev 367/10-2. 
da jedna stranka nadoknadi drugoj i umješaču razmjeran dio troškova. ${ }^{38}$

Sud može odlučiti da jedna stranka nadoknadi sve troškove koje su protivna stranka i njezin umješač $\breve{3}^{39}$ imali, ako protivna stranka nije uspjela samo u razmjerno neznatnom dijelu svog zahtjeva, a zbog tog dijela nisu nastali posebni troškovi.

Prema rezultatu dokazivanja, sud će odlučiti hoće li troškove iz čl. 153. st. 5. podmirivati jedna ili obje stranke ili će ti troškovi pasti na teret sredstava suda (čl. 154. Novele 2019.).

Kada je u pitanju utvrđivanje omjera uspjeha u parnici kod djelomičnog uspjeha stranaka u parnici, koje je zadnjih godina izazivalo brojne prijepore, novelirani st. 2. čl. 154. ZPP-a pokušao je riješiti neke od uočenih dvojbi. Pritom valja spomenuti i presudu Europskog suda za ljudska prava u predmetu Klauz protiv Hrvatske, ${ }^{40}$ koja je zasigurno potaknula zakonodavca na takvo rješenje. ${ }^{41}$

Uvođenje ovoga novog rješenja u parnični postupak izazvalo je brojne kritike struke. ${ }^{42}$ Kod djelomičnog uspjeha stranaka u sporu, zakonodavac je predvidio, iako dvojbenu, vrlo detaljnu, opširnu i razrađenu formulu. S druge strane, za rješavanje složene situacije izračuna parničnih troškova pri promjeni visine zahtjeva nudi iznimno koncizno i pojednostavnjeno rješenje. Istodobno, za uvođenje te važne novine u parnični postupak zakonodavac ne daje gotovo nikakvo obrazloženje. ${ }^{43}$ Ova odredba odstupa od prakse VSRH koji je tijekom godina zauzimao shvaćanje da se kod promjene vrijednosti predmeta spora parnični troškovi računaju prema vrijednosti predmeta spora tijekom poduzimanja parnične radnje. ${ }^{44}$

Dakle, ovomje odredbom propisano da se naknada troškova u slučaju djelomičnog uspjeha u parnici računa prema postotku uspjeha u odnosu na konačno postavljeni tužbeni zahtjev, tako da se najprije utvrdi postotak u kojemu je svaka od njih uspjela,

38 Prema odredbi čl. 154. st. 2. ZPP-a, ako stranka djelomično uspije u parnici, sud može s obzirom na postignuti uspjeh, odrediti da svaka stranka snosi svoje troškove ili da jedna stranka nadoknadi drugoj i umješaču razmjerni dio troškova. (a kako to proizlazi i iz odluka ovog suda na koje se tužitelj poziva u reviziji: Rev - 1083/09 od 15. listopada 2009., te odluka Rev - 832/05 od 26. travnja 2007., Rev - 885/06 od 20. rujna 2007.)., VSRH, Revr 119/12-2.

39 Mihajlo Dika, „O troškovnom statusu umješača nakon Novele Zakona o parničnom postupku iz 2019.", u: Zbornik radova s V. međunarodnog savjetovanja Aktualnosti građanskog procesnog prava - nacionalna i usporedna pravnoteorijska i praktična dostignuća, [Split], 17. i 18. listopada 2019. godine, ur. Dinka Šago et al., 1-34. (Split: Pravni fakultet Sveučilišta u Splitu, 2019.), $1 \mathrm{i} \mathrm{slj.}$

40 Presuda Europskog suda za ljudska prava Klauz protiv Hrvatske (zahtjev br. 28963/10) od 18. srpnja 2013., konačna 09/12/2013, pristup 18. prosinca 2020., https://uredzastupnika.gov.hr/ UserDocsImages//arhiva//KLAUZ\%20presuda.pdf27, 27.

41 Damir Jelušić, „Utjecaj presude Europskog suda za ljudska prava u predmetu Klauz protiv Hrvatske na tuzemne sudove“, Pravo i porezi br. 4 (2018): 63-67.

42 Izvješće o provedenom savjetovanju - Savjetovanje o Nacrtu prijedloga Zakona o izmjenama $i$ dopunama Zakona o parničnom postupku, pristup 17. prosinca 2020., https://esavjetovanja.gov. $\mathrm{hr} /$ ECon/EconReport?entityId=9786.

43 Vučković, Promjena visine tužbenog zahtjeva i naknada troškova parničnog postupka.

44 Pri odlučivanju o troškovima postupka treba voditi računa o vrijednosti predmeta spora tijekom poduzimanja svake parnične radnje, pa budući da je smanjenje tužbenog zahtjeva djelomično povlačenje tužbe, ono je, pa makar i djelomično, neuspjeh tužitelja. U tom smislu presuđeno: VSRH, Revr 1426/10-2 od 2. veljače 2011. 
zatim od postotka one stranke koja je u većoj mjeri uspjela oduzme postotak one stranke koja je u manjoj mjeri uspjela. Nakon toga će utvrditi iznos pojedinih i iznos ukupnih troškova stranke koja je u većoj mjeri uspjela u parnici, a koji su bili potrebni za svrhovito vođenje postupka. ${ }^{45}$ Toj stranci sud će odmjeriti naknadu dijela ukupnog troška koji odgovara postotku koji je preostao nakon navedenog obračuna postotaka u kojima su stranke uspjele u parnici. ${ }^{46}$ Novina je i to da se propisuje kako omjer uspjeha u parnici sud ocjenjuje prema konačno postavljenom tužbenom zahtjevu.

Sud će dakle, stranci s većim uspjehom priznati troškove prema razlici uspjeha obje stranke:

- najprije će se utvrditi postotak u kojem je svaka stranka uspjela,

- potom će se od postotka stranke koja je u većem omjeru uspjela oduzeti postotak one sa manjim iznosom uspjeha,

- s obzirom na utvrđene ukupne i pojedine troškove odredit će se naknada onoj stranci s većim omjerom uspjeha prema dijelu koji je preostao nakon prethodno navedenog obračuna postotaka,

- djelomični trošak tako se utvrđuje i prema konačno postavljenom tužbenom i ovisno o uspješnosti dokazivanja parničnih procesa. ${ }^{47}$

Takav način odlučivanja o troškovima postupka kada se dosuđuju troškovi tužitelju u postotku u kojem je uspio u sporu, zatim tuženiku u postotku u kojem je uspio u sporu te odbijanjem jednog troška od drugog, tužitelj se, matematički gledano, dva puta „kažnjava“ za odbijajući dio tužbenog zahtjeva. S druge strane, tuženik se (koji je, nemojmo zaboraviti, dao povoda tužbi i isprovocirao parnični postupak, ne želeći odnose s tužiteljem riješiti mirnim putem i izvan suda) nagrađuje time što ne mora platiti dio troškova tužitelja, a zatim mu se još priznaje i dio njegovih troškova. ${ }^{48}$ U praksi, je takvo stajalište naišlo na osudu upravo zbog zanemarivanja troškova one strane koja je imali manji udjel u djelomičnom uspjehu. Smatra se da dovodi do nepravde za tužitelja, koji se s punim povjerenjem obraća sudu vjerujući u pravičnost propisa i pošteno suđenje.

45 Više Vladimir Vučković, ,Troškovi parničnog postupka kod djelomičnog uspjeha stranaka u sporu prema Nacrtu prijedloga Zakona o parničnom postupku“, Hrvatska pravna revija br. 4 (2017): 85-87.

46 U presudi VSRH, Rev-885/2006 od 20. rujna 2016. prikazan je način izračuna troškova postupka kod djelomičnog uspjeha stranaka (omjer 40:60 u korist tuženika) u parnici na sljedeći način: Tužiteljica je imala parnični trošak za sastav tužbe u visini od 330 bodova (tbr. 7. toč. 1. Tarife) za zastupanje na ročištima 21. listopada 2002., 18. svibnja 2003. i 21. studenog 2003. godine, ukupno 990 bodova (Tbr. 9 Tarife), odnosno ukupno 1320 bodova što s PDV-om iznosi 1610 kn (tužiteljica nije tražila naknadu za sastav tužbe i revizije). Tužiteljica je uspjela u parnici u omjeru koji iznosi 40 \%, te joj kao opravdani parnični trošak pripada iznos od 6441,60 kn. Tuženik je imao trošak sudskih pristojbi na tužbu i presudu u iznosu 6700,00 kn s tim da je uspio u protivljenju tužbenom zahtjevu u omjeru od $60 \%$ (u kojem omjeru je tuženik uspio u parnici) pa mu opravdani trošak pripada iznos 4020,00 kn. Nakon izvršenog prijeboja parničnih troškova tuženom je naloženo da plati tužiteljici parnični trošak u iznosu od 2421,60 $k n$. Vidi kod Vladimir Vučković, „Nedavanje povoda za tužbu i naknada troškova parničnog postupka“, Odvjetnik br. 11/12 (2018): 29.

47 Odluka VSRH, Rev 200/01 od 6. rujna 2001., Rev 609/01 od 22. svibnja 2001. prema kojoj i tužitelj i tuženik imaju razmjerni uspjeh u sporu.

48 Bulka, Troškovi parničnog postupka i matematika, 84. 
Neki autori ${ }^{49}$ smatraju da su se u Novelu ZPP 2019. morala umetnuti još neka rješenja iz relevantne judikature, ${ }^{50}$ primjerice pravilo o obračunu i naknadi parničnih troškova u situaciji u kojoj tužitelj jednom ili višekratno djelomično povuče tužbu smanjenjem glavnoga tužbenog zahtjeva. ${ }^{51}$

Naposljetku, ovdje moramo primijetiti da je nejasno i neodređeno kako će, sadašnjim normiranjem, parnični sud, nakon što utvrdi novčani iznos koji je parnična stranka s manjim parničnim uspjehom obvezna namiriti stranci s većim uspjehom, procijeniti koliki je kvalitativni djelomični uspjeh i onda taj uspjeh izražen u postotcima preračunati u novčani iznos troškova i pribrojiti ga iznosu dobivenom putem izračuna formulom, da bi se tako dobio zbirni novčani iznos kojeg je stranka s manjim djelomičnim uspjehom u sporu dužna namiriti stranci s većim, a sve po sudu, procijenjenim kvalitativnim i kvantitativnim djelomičnim uspjehom stranaka. Neki autori predlažu da se izrijekom propiše da kada su stranke djelomično uspjele u parnici, sud prvo utvrdi postotak u kojemu je svaka od njih uspjela, pritom vodeći računa i o uspjehu dokazivanja u pogledu osnove zahtjeva, zatim da od postotka one stranke koja je u većoj mjeri uspjela oduzme postotak one stranke koja je u manjoj mjeri uspjela. Nakon toga će utvrditi iznos pojedinih i iznos ukupnih troškova stranke koja je u većoj mjeri uspjela u parnici koji su bili potrebni za svrhovito vođenje postupka te će toj stranci odmjeriti naknadu dijela takvih ukupnih troškova koji odgovara postotku koji je preostao nakon navedenog obračuna postotaka u kojima su stranke uspjele u parnici, pri čemu se omjer uspjeha u parnici ocjenjuje prema konačno postavljenom tužbenom zahtjevu. ${ }^{52}$

\section{GUBITAK I DJELOMIČNI GUBITAK PARNICE}

Stranka koja u cijelosti izgubi parnicu dužna je protivnoj stranci i njezinu

49 Jelušić, Novo normativno rješenje instituta naknade parničnih troškova u situaciji parcijalnog uspjeha u sporu.

50 U praksi VSRH nailazimo na stajalište da u slučaju smanjenja tužbenog zahtjeva tuženik nema pravo na naknadu parničnih troškova za smanjeni dio zahtjeva ako su troškovi izračunani prema vrijednosti predmeta spora prijašnjeg zahtjeva jednaki ili veći troškovima smanjenog tužbenog zahtjeva. Vladimir Vučković, „Troškovi parničnog postupka kod smanjenja tužbenog zahtjeva - kritika stajališta Vrhovnog suda Republike Hrvatske", Hrvatska pravna revija br. 12 (2016): 76-78.

51 Nijeosnovananirevizija tužitelja zbogodlukeotroškovima parničnog postupka. Drugostupanjski sud je pravilno ocijenio uspjeh tužitelja u sporu sa $70 \%$, a tuženog sa $30 \%$, pa je primjenom odredbe čl. 154. st. 2. ZPP-a dosudio tužitelju srazmjeran dio troškova parničnog postupka. Drugostupanjski je sud obračunao troškove parničnog postupka tužitelju prema vrijednosti smanjenog tužbenog zahtjeva, jer smanjenje tužbenog zahtjeva znači povlačenje tužbe $s$ prvobitno postavljenog na smanjeni iznos tužbenog zahtjeva, pa su primjenom odredbe čl. 193. u svezi s odredbom čl. 154. st. 2. ZPP-a tužitelju pravilno priznati troškovi parničnog postupka prema vrijednosti konačno postavljenog tužbenog zahtjeva za sve parnične radnje od tužbe pa nadalje, a tuženiku prema vrijednosti spora navedenog u tužbi, jer tako za slučajeve povlačenja tužbe propisuje odredba članka 158. stavak 1. u svezi sa člankom 164. stavak 7. ZPP-a., VSRH, Rev-2183/1998-2.

52 Tako Jelušić, Novo normativno rješenje instituta naknade parničnih troškova u situaciji parcijalnog uspjeha u sporu. 
umješaču naknaditi troškove izazvane vođenjem postupka. ${ }^{53}$ Umješač na strani stranke koja je izgubila parnicu obvezan je naknaditi troškove koje je prouzročio svojim radnjama. ${ }^{54}$

Nova su pravila o obračunu troškova kada su obje stranke djelomično uspjele u parnici. Tako je kao prvo određeno da će sud najprije utvrditi postotak u kojem je svaka od njih uspjela u postupku. Omjer uspjeha u parnici ocjenjuje se prema konačno postavljenom tužbenom zahtjevu, vodeći računa i o uspjehu dokazivanja u pogledu osnove zahtjeva. Dakle, izmjene tužbenog zahtjeva tijekom parnice više neće utjecati na obračun troškova postupka, jer je izričito propisano da će se omjer uspjeha u parnici ocjenjivati prema konačno postavljenom tužbenom zahtjevu. No, obračun omjera uspjeha u parnici nije sam povezan s vrijednosti pojedinih zahtjeva nego će sud uzimati u obzir i činjenicu je li tuženik osporavao osnovu i visinu tužbenog zahtjeva. ${ }^{55}$

To je pravilo povezano s osnovom tužbenog zahtjeva, u pravilu, primjenjivo onda kada se tužbeni zahtjev odnosi na naknadu štete, ali moguće je i u drugim slučajevima kada se osporava visina i osnova zahtjeva. Nije izrijekom propisano kako će sud obračunavati troškove, odnosno hoće li se uspjeh u dokazivanju osnove tužbenog zahtjeva uzimati kao uspjeh od $50 \%$, a u drugih $50 \%$ će se računati uspjeh povezan s visinom tužbenog zahtjeva, stoga će u konačnici sudska praksa utvrditi kako će se točno računati taj omjer uspjeha u postupku.

Nakon što sud obračuna postotak uspjeha u postupku za svaku stranku, potom će od postotka one stranke koja je u većoj mjeri uspjela oduzeti postotak one stranke koja je u manjoj mjeri uspjela.

Primjenom te nove metode obračuna, sud više neće računati sve troškove za svaku stranku, kao što je to do sada bilo, nego će utvrditi vrste i svote troškova stranke koja je u većoj mjeri uspjela u parnici. Pritom će uzeti u obzir samo one troškove koji su bili potrebni za svrhovito vođenje postupka te će toj stranci odmjeriti naknadu dijela takvih ukupnih troškova koji odgovara postotku koji je preostao nakon navedenog obračuna postotaka u kojima su stranke uspjele u parnici.

Dakle, sud sada više ne računa postotak uspjeha svake stranke i svakoj stranci dosuđuje troškove, nego će dosuditi potrebne troškove samo onoj stranci koja je u

53 Ovaj je članak mijenjan na temelju čl. 28. ZID ZPP 19, a na temelju čl. 117. st. 3. ZID ZPP 19 izmjena se primjenjuje na sve postupke u tijeku u kojima do 1. rujna 2019. nije donesena prvostupanjska odluka. Odredbom iz čl. 117. st. 2. Zakona o izmjenama i dopunama zakona o parničnom postupka (Narodne novine, br. $70 / 19$., dalje: ZID) propisano je da će se (između ostalih) odredba iz čl. 28. ZID-a kojom je izmijenjen čl. 154. ZPP-a primjenjivati na sve postupke u tijeku, iako su pokrenuti prije stupanja na snagu ZID-a. Pri odluci o parničnom trošku ovaj je sud utvrdio postotak uspjeha obje stranke. Obje su stranke uspjele u jednakom postotku (50\%), stoga svaka stranka snosi svoje troškove postupka, a budući da je tužiteljica djelomično uspjela sa žalbom pripada joj trošak sastava žalbe u iznosu od 875,00 kn (50 \% od 1.750,00). U tom smislu presuđeno: Županijski sud u Dubrovniku, Gž 148/2020-2.

54 Za odgovornost umješača prema novom pravilu, koje je smješteno među odredbama o naknadi troškova po odgovornosti za uspjeh, kada je stranka na čijoj se strani pridružio umješač pretrpjela neuspjeh u parnici, trebale bi biti ispunjene dvije pretpostavke: 1. da je stranka na čijoj se strani pridružio umješač izgubila parnicu, i to treba uzeti u cijelosti te 2 . da je riječ o radnjama koje je poduzeo umješač (čl. 154. st. 1. reč. 2. ZPP-a).

55 Tako Jelena Čuveljak, „Troškovi parničnog postupka“, Pravo i porezi br. 10 (2019): 44. 
većoj mjeri uspjela u postupku. Sudu je time olakšan obračun troškova uspjeha u postupku, a navedeni je novi sustav povoljniji za stranku koju zastupaju osobe koje nemaju pravo na naknadu troškova zastupanja.

Iako je osnovno pravilo da će se trošak nadoknaditi prema uspjehu u postupku, sud može odrediti da jedna stranka naknadi drugoj stranci pojedine troškove koje je prouzročila svojom krivnjom ili slučajem koji se njoj dogodio. Dakle, ako je, npr. do odgode ročišta došlo jer jedna od stranaka nije došla, onda sud može odrediti da trošak tog ročišta naknađuje odgovorna stranka, neovisno o uspjehu u postupku.

Neovisno o novim pravilima obračuna troškova kod djelomičnog uspjeha u postupku, i nadalje je zadržano pravilo da sud može odlučiti da jedna stranka nadoknadi sve troškove koje su protivna stranka i njezin umješač imali ako protivna stranka nije uspjela samo u razmjerno neznatnom dijelu svog zahtjeva, a zbog tog dijela nisu nastali posebni troškovi. Dakle, za primjenu tog pravila bitno je da jedna strana nije uspjela u samo neznatnom dijelu svog zahtjeva, no uz uvjet da za taj dio zahtjeva nisu nastali posebni troškovi.

Ako su stranke djelomično uspjele u parnici u približno jednakim dijelovima, sud može odrediti da svaka stranka snosi svoje troškove ili da jedna stranka naknadi drugoj stranci samo pojedine troškove primjenom pravila o naknadi troškova koje je stranka prouzročila svojom krivnjom ili slučajem koji se njoj dogodio. Približno jednaki dio uspjeha u parnici ne mora biti točan omjer uspjeha u postupku na pola, već sud može tu odluku donijeti uzimajući u obzir sve okolnosti konkretnog slučaja i sve troškove koji su bili potrebni za uspjeh u postupku. Sada je ovo još jasnije, jer zakonodavac nije propisao da je riječ o jednakom uspjehu u postupku nego u približno jednakom dijelu.

Ako je tijekom postupka sud po službenoj dužnosti izvodio određene dokaze za koje stranke nisu unaprijed položile svotu potrebnu za naknadu tih troškova, nego je svota toga troška plaćena iz proračunskih sredstava suda, na kraju postupka, a prema rezultatu dokazivanja, sud će odlučiti hoće li te troškove podmirivati jedna ili obje stranke ili će ti troškovi pasti na teret sredstava suda.

\section{ZAKLJUČNA RAZMATRANJA}

Iako nisu glavni tužbeni zahtjev, odlučivanje o troškovima parničnog postupka katkad je složenije od odlučivanja o glavnom zahtjevu. To ponajprije zbog složenosti parničnog postupka i odredaba koje uređuju troškove parničnog postupka, ali i različite sudske prakse. Posebno su izražena različita mišljenja kod konačnog snošenja troškova parničnog postupka u slučaju djelomičnog uspjeha u sporu, što utječe i na pravnu sigurnost stranaka.

Novelom 2019. olakšava se odmjeravanje troškova postupka budući da se izbjegava (dosadašnji) izračun troškova jedne i druge stranke kod djelomičnog uspjeha u postupku i potom "prebijanje" tih troškova. To je dosada bila praksa koju svi drugostupanjski sudovi nisu slijedili jer, prema mišljenju nekih, za navedeno "prebijanje" nije bilo uporišta u ZPP-u, stoga su troškove postupka dosuđivali isključivo jednoj stranci, u pravilu tužitelju i to razmjerno njegovu uspjehu u sporu. 
Dakle, prvotno će se utvrditi postotak uspjeha svake od stranaka, s tim da je Novelom 2019., otklonjena i daljnja nejasnoća u dosadašnjoj praksi time što se taj postotak sada utvrđuje prema konačno postavljenom tužbenom zahtjevu. Uz to, pri prosudbi uspjeha valjalo bi voditi računa i o uspjehu stranke u dokazivanju osporavane pravne osnove tužbenog zahtjeva, uzimajući u obzir koliko je to samo po sebi utjecalo na ukupne troškove postupka, a ne samo promatrajući uspjeh stranaka (matematički) isključivo u odnosu na visinu tužbenoga zahtjeva. ${ }^{56}$

Trošak parničnog postupka određuje se, a ovdje nije riječ o konačnom odmjeravanju troškova, već o izračunu pojedinog troška u odnosu na svaku parničnu radnju, sukladno vrijednosti predmeta spora koja je vrijedila u trenutku poduzimanja pojedinih parničnih radnji, a ne prema vrijednosti predmeta spora koja je eventualno vrijedila pri zaključenju glavne rasprave. U odnosu na situacije u kojima je jedna stranka djelomično povukla tužbu, rješenje se nalazi u naknadi troškova za povučeni dio prema odredbama čl. 158. st. 1. ZPP-a, dakle, tu zbog povlačenja nije potrebno ocjenjivati uspjeh u postupku. O tome su već zauzeta pravna shvaćanja u revizijskim odlukama..$^{57,58}$

56 Tako Dragan Katić, „Zašto (opet) nove izmjene Zakona o parničnom postupku“, u: Zbornik radova s II. međunarodnog savjetovanja "Aktualnosti građanskog procesnog prava nacionalna i usporedna pravnoteorijska i praktična dostignuća”, [Split], 21. i 22. listopada 2016., ur. Vesna Rijavec et al., 143-170 (Split: Pravni fakultet, 2016.).

57 Marko Bratković i Dragan Katić, Novo uređenje revizije, Priručnik za polaznike, Zagreb: Pravosudna akademija, 2019., 1-34.

58 VSRH, Revr 845/09-2 od 12. siječnja 2010., navodi se sljedeće: Tuženik je kao drugo pravno pitanje naveo pogrešno odmjeravanje $i$ dosuđenje parničnog troška u odnosu na vrijednost predmeta spora u trenutku poduzimanja pojedinačnih parničnih radnji. Tuženik je potpuno u pravu da se trošak parničnog postupka određuje sukladno vrijednosti predmeta spora, a koja vrijednost je vrijedila u trenutku poduzimanja pojedinih parničnih radnji a ne prema vrijednosti predmeta spora koja je eventualno vrijedila prilikom zaključenja glavne rasprave. Ovaj sud je u svojim ranijim odlukama zauzeo istovrsno pravno shvaćanje (primjerice u odluci Revt-35/04-2 od 14. lipnja 2005. i Rev-402/04 od 21. rujna 2005.). Stoga tuženiku pripada trošak zastupanja prema Tarifi o nagradama i naknadi troškova za rad odvjetnika ("Narodne novine”, broj 91/04, 37/05 i 59/07 - dalje: Tarifa) sukladno vrijednosti predmeta spora koja je vrijedila u trenutku poduzimanja pojedine parnične radnje. (...). Nižestupanjski sudovi su kod obračuna tuženiku troškova parničnog postupka isti obračunali na način da su primijenili vrijednost predmeta spora za cijeli postupak u visini nakon zadnjeg sniženja tužbenog zahtjeva na iznos od 83.926,08 kune, te su razmjerno uspjehu u parnici obračunali trošak tuženiku $i$ tužitelju. Nije uzeto u obzir da je tužitelj zapravo povukao tužbu za onaj dio za koji je smanjen tužbeni zahtjev $i$ da se tuženiku kod obračuna troškova parničnog postupka u odnosu na dio tužbenog zahtjeva za koje je tužba povučena treba trošak obračunati u skladu s odredbom čl. 158. st. 1. ZPP. Kod toga treba napomenuti da prema pravnom shvaćanju ovog suda kod ovakvog djelomičnog povlačenja tužbe sud nije dužan postupiti u smislu čl. 164. st. 7. ZPP budući je riječ o djelomičnom povlačenju tužbe koje nema za posljedicu okončanje postupka pred prvostupanjskim sudom, već se procesne aktivnosti stranaka nastavljaju tako da u trenutku smanjenja tužbenog zahtjeva ukupni troškovi i konačni uspjeh stranaka u sporu još nisu poznati, a o naknadi parničnih troškova koji se odnose na smanjeni dio tužbenog zahtjeva sud treba odlučiti u odluci o glavnoj stvari, kod čega će tuženik naknadu troškova u odnosu na povlačenje tužbe ostvarivati zajedno sa naknadom troškova obračunatih obzirom na konačno postavljen tužbeni zahtjev i razmjerno uspjehu u parnici. 
Novo normativno uređenje troškova postupka dijelom je nejasno, odnosno neodređeno u odnosu na dosadašnje rješenje i postojeću relevantnu sudsku praksu. Zakonodavac, umjesto da uređuje način obračuna troškova koji je uhodan u praksi, uz uklanjanje nekih njegovih nedostataka, propisuje novu proceduru obračuna koja pri izračunu ne uzima u obzir troškove postupka one strane koja je u manjem dijelu djelomično uspjela u parnici.

Spornim smatramo omjer uspjeha stranaka u sporu izračunat prema konačno postavljenom tužbenom zahtjevu, a istodobno visinu parničnih troškova prema vrijednosti predmeta spora u trenutku poduzimanja parnične radnje.

Iako ima dosta posebnih pravila o naknadi troškova postupka, ipak ovim pravilima nisu riješeni svi praktični problemi. ${ }^{59}$ Iako se navedenim pravilima željelo olakšati donošenje odluke o troškovima postupka, ipak i nadalje odluku o troškovima donosi sud svaki put kada donosi i odluku o glavnoj stvari, a u složenijim je slučajevima moguće da odluku donose sudovi prvog i drugog stupnja, i to više puta. Stoga bi zbog ekonomičnosti postupanja bilo dobro razmisliti je li nužno svaki put donositi odluku ili se o troškovima postupka može donijeti odluka nakon pravomoćnosti odluke o glavnoj stvari.

\section{LITERATURA}

1. Aras Kramar, Slađana, „Troškovi parničnog postupka - osvrt na važna pitanja “. Pravo $i$ porezi br. 10 (2020): 48-56.

2. Barać Ručevič, Goranka i Senija Ledić. Troškovi parničnog postupka, Priručnik za polaznike/ice, Zagreb: Pravosudna akademija, 2018.

3. Bratković, Marko i Dragan Katić. Novo uređenje revizije, Priručnik za polaznike, Zagreb: Pravosudna akademija, 2019.

4. Bulka, Zinka. „Troškovi parničnog postupka i matematika- (ne)pravda za tužitelja“, Pravo i porezi 21, br. 7-8 (2012): 80-84.

5. Čizmić, Jozo. Komentar Zakona o parničnom postupku. 2. izmijenjeno i dopunjeno izd. Sarajevo: Privredna štampa, 2016.

6. Čuveljak, Jelena. „Troškovi parničnog postupka“. Pravo i porezi br. 10 (2019): 42-46.

7. Dika, Mihajlo. „Konačno snošenje troškova parničnog postupka, Pokušaj sustavne prezentacije i redefiniranje instituta“. Pravo u gospodarstvu 44, br. (2005): 54-90.

8. Dika, Mihajlo. „Naknada troškova u slučaju povlačenja tužbe i odricanja od tužbenog zahtjeva prema noveliranom Zakonu o parničnom postupku“. Zbornik Pravnog fakulteta Sveučilišta u Rijeci 41, br. 1 (2020): 1-40.

9. Dika, Mihajlo. „O troškovnom statusu umješača nakon Novele Zakona o parničnom postupku iz 2019.”. U: Zbornik radova s V. međunarodnog savjetovanja Aktualnosti građanskog procesnog prava - nacionalna $i$ usporedna pravnoteorijska i praktična dostignuća, [Split], 17. i 18. listopada 2019. godine, ur. Dinka Šago, Jozo Čizmić, Vesna Rijavec, Arsen Janevski, Vesna Lazić Smoljanić, Milijan Sesar, Aleš Galič, 1-34. Split: Pravni fakultet Sveučilišta u Splitu, 2019.

10. Hrvatin, Branko. „Naknada troškova parničnog postupka“. Hrvatska gospodarska revija 47, br. 11 (1998): 1305-1310 (35-40).

59 Primjerice i dalje nije jasno propisano tko snosi troškove parničnog postupka koji je pokrenut radi utvrđivanja osnovanosti osporavanja tražbine kada stečajnog dužnika ne zastupa stečajni upravitelj nego vjerovnik koji je osporio određenu tražbinu. Vidi Čuveljak, Troškovi parničnog postupka, 42-46. 
11. Jelinić, Damir. „(Po)nešto o nedopuštenosti revizije protiv pravomoćnog rješenja o naknadi troškova parničnog postupka“, Hrvatska pravna revija, br. 7/8 (2016): 72-78.

12. Jelušić, Damir. „Novo normativno rješenje instituta naknade parničnih troškova u situaciji parcijalnog uspjeha u sporu“. Pravo i porezi, 11 (2019): 82-85. Pristup 22. prosinca 2020., https://www.iusinfo.hr/strucni-clanci/CLN20V01D2019B1291.

13. Jelušić, Damir. „Utjecaj presude Europskog suda za ljudska prava u predmetu Klauz protiv Hrvatske na tuzemne sudove“. Pravo i porezi br. 4 (2018): 63-67.

14. Katić, Dragan. „Zašto (opet) nove izmjene Zakona o parničnom postupku“. U: Zbornik radova s II. međunarodnog savjetovanja "Aktualnosti građanskog procesnog prava - nacionalna i usporedna pravnoteorijska i praktična dostignuća”, [Split], 21. i 22. listopada 2016., ur. Vesna Rijavec, Arsen Janevski, Aleš Galič, Jozo Čizmić, Vesna Lazić Smoljanić, Milijan Sesar i Dinka Šago, 143-170. Split: Pravni fakultet, 2016.

15. Katić, Dragan, Željko Pajalić i Aleksandra Maganić. Izmjene Zakona o parničnom postupku. Priručnik za polaznikelpolaznice, Izrada obrazovnog materijala. Zagreb: Pravosudna akademija, 2019.

16. Milošević, Sanja. „Pretprocesni parnični troškovi“. Aktualnosti hrvatskog zakonodavstva i pravne prakse: građansko, trgovačko, radno i procesno pravo u praksi 22 (2015): 683690.

17. Poljić, Adis. Troškovi parničnog postupka i vrijednost predmeta spora. Sarajevo: Privredna štampa, 2019.

18. Prančić, Vicko. „O naknadi pretprocesnih troškova u parničnom postupku“. Zbornik Pravnog fakulteta u Splitu 47, br. 4 (2010): 861-886.

19. Presuda Europskog suda za ljudska prava Klauz protiv Hrvatske (zahtjev br. 28963/10) od 18. srpnja 2013. Konačna 09/12/2013, https://uredzastupnika.gov.hr/UserDocsImages// arhiva//KLAUZ\%20presuda.pdf27.

20. Prijedlog Zakona o izmjenama i dopunama Zakona o parničnom postupku, Vlada Republike Hrvatske, Zagreb, 29. ožujka 2019., https://www.sabor.hr/sites/default/files/ uploads/sabor/2019-03-28/155302/PZ_620.pdf

21. PSH Pž-3325/90 od 14. siječnja 1992.

22. Tarifa o nagradama i naknadi troškova za rad odvjetnika, Narodne novine, br. 142/12., 103/14., 118/14., 107/15.

23. Triva, Siniša i Mihajlo Dika. Građansko parnično procesno pravo. 7. izmijenjeno i dopunjeno izd. Zagreb: Narodne novine, 2004.

24. VRSH, Rev-x 502/12-2.

25. VSRH, Rev 200/01 od 6. rujna 2001.

26. VSRH, Rev 200/2001.

27. VSRH, Rev 200/2001-2.

28. VSRH, Rev 2141/1995.

29. VSRH, Rev 2141/1995.

30. VSRH, Rev 2183/1998-2.

31. VSRH, Rev 367/10-2.

32. VSRH, Rev $388 / 00$ od 26. kolovoza 2003.

33. VSRH, Rev 583/09 od 17. rujna 2013.

34. VSRH, Rev 609/01 od 22. svibnja 2001.

35. VSRH, Rev 616/2006-2.

36. VSRH, Rev 817/13-2.

37. VSRH, Rev 832/05-2.

38. VSRH, Rev 885/2006 od 20. rujna 2016.

39. VSRH, Rev 885/2006-2.

40. VSRH, Revr 119/12-2.

41. VSRH, Revr 119/12-2.

42. VSRH, Revr 1345/09 od 12. siječnja 2010. 
43. VSRH, Revr 1426/10-2 od 2. veljače 2011.

44. VSRH, Revr 845/09-2 od 12. siječnja 2010.

45. VSRH, Rev 3146/1990.

46. Vučković, Vladimir. „Nedavanje povoda za tužbu i naknada troškova parničnog postupka“. Odvjetnik br. 11/12 (2018): 29-33.

47. Vučković, Vladimir. „Promjena visine tužbenog zahtjeva i naknada troškova parničnog postupka - kritika novog zakonodavnog rješenja“. Informator 67. br. 6588 (2019): 1-4. Pristup 19. prosinca 2020., https://informator.hr/strucni-clanci/promjena-visine-tuzbenogzahtjeva-i-naknada-troskova-parnicnog-postupka-kritika-novog-zakonodavnog-rjesenja.

48. Vučković, Vladimir. „Troškovi parničnog postupka kod djelomičnog uspjeha stranaka u sporu prema Nacrtu prijedloga Zakona o parničnom postupku“. Hrvatska pravna revija br. 4 (2017): 85-87.

49. Vučković, Vladimir. „Troškovi parničnog postupka kod smanjenja tužbenog zahtjeva - kritika stajališta Vrhovnog suda Republike Hrvatske". Hrvatska pravna revija br. 12 (2016): 76-78.

50. Zakon o parničnom postupku, Narodne novine, br. 53/91., 91/92., 112/99., 88/01., 117/03., 88/05., 2/07. - Odluka US RH, 84/08., 96/08. - Odluka US RH, 123/08. - ispravak, 57/11., 148/11., 25/13., 28/13., 89/14., 70/19.

51. Županijski sud u Dubrovniku, Gž 148/2020-2. 


\title{
Dinka Šago*
}

\author{
Summary
}

\section{CIVIL PROCEDURE COSTS}

In this article the author analyzes certain solutions of the Amendment of the Civil Procedure Act from 2019 on the reimbursement of costs according to the principle of responsibility for success and responsibility for guilt or case.

The paper outlines the most significant novelties, the novelties are analyzed in relation to the partial success of the parties to the litigation, the success in proving the basis of the claim, the change in the value of the subject matter of the dispute during the litigation, the participation of the intervener, the withdrawal of the claim and the waiver of the claim.

Keywords: costs; litigation; partial success of parties to the dispute.

* Dinka Šago, Ph.D., Associate Professor, Faculty of Law, University of Split; dsago@pravst.hr. ORCID: https://orcid.org/0000-0002-2957-2761. 